\title{
Combatting Antisemitism: An Interdisciplinary Approach
}

The following considerations adhere to an interdisciplinary approach to the subject of religiously-motivated antisemitism, which is often referred to as anti-Judaism. The first part provides a brief historical overview. The intent here is to demonstrate that first of all, one cannot underestimate the importance of Christianmotivated antisemitism for the spread of antisemitism in general, and second of all, one has to take into account the importance of the antithetical evaluation pattern. For this reason, in my view anti-Judaism is the Christian-religious part of antisemitism in general. In the second part, attention will be drawn to antiJewish contrasting in religious education, which constitutes more or less the same black and white pattern as described in the historical part. In the third part, the psychological perspective shows why and how the antithetical evaluation pattern is the source of anti-Jewish prejudices. The psychological aspects are also important because they explain how religious education can contribute to combatting religiously-motivated antisemitism, which is the topic of the last part.

\section{Historical Perspectives ${ }^{1}$}

\subsection{On the Origin of Anti-Jewish Contrasting}

For Christians, Judaism is not just any religion among others. The Christian faith originated wholly within the framework of Judaism; the initial step towards the "law-free" Gentile mission was initiated primarily through the so-called Council of Jerusalem that convened about fifteen years after the death of Jesus. There was no reason to suppose that Gentile Christians would play a dominant role in the future, nor that Jewish Christians would be relegated to a marginal one. At this time, Christians considered themselves as belonging to the Jewish religion. Accordingly, Christianity was situated in a tense relationship with Judaism, one

1 This chapter is a slightly modified version of M. Rothgangel, "Anti-Semitism as a Challenge for Religious Education,” in Religious Education: Between Radicalism and Tolerance, ed. E. Aslan and M. Rausch (Wiesbaden: Springer, 2018), 35-51, esp. 36-39.

๑ OpenAccess. ( 2019 Martin Rothgangel, published by De Gruyter. (cc))BY-NC-ND This work is licensed under the Creative Commons Attribution-NonCommercial-NoDerivatives 4.0 License. 
that is characterized by both continuity and discontinuity. ${ }^{2}$ With that said, the ensuing history reveals that while discontinuity was increasingly stressed, continuity was consistently downplayed.

In addition to this, from the Jewish perspective, the works of Jesus Christ affected neither the expected restoration of the Davidic kingdom nor the coming of the Kingdom of God. By contesting the messiahship of Jesus, however, Judaism put-and continues to put-the truth and center of the Christian faith to a fundamental test. A decisive cause of the emergence of an anti-Jewish Christian identity is that the Christian community was initially an internal Jewish group. Accordingly, for Christians, the Jewish "mother-religion" can question their self-conception and identity like no other religion.

In his essay "Judaism as Antithesis: On the Tradition of a Cultural Evaluation Pattern," ${ }^{3}$ Christhard Hoffmann argues convincingly that the perception and evaluation of Judaism was often characterized by a polarity of black and white, in which Judaism always found itself representing the negative pole. ${ }^{4}$ According to Hoffmann, the origin of this antithetical evaluation pattern, which proved so fateful for Judaism, is grounded in Christian theology. ${ }^{5}$ Indeed, Christian identity is seldom articulated without Judaism being brought up as a foilone that serves as a dark contrast against which Christian identity can stand out all the brighter. The definition of this relationship lends itself to an evident black/white orientation:

\begin{tabular}{|c|c|c|c|c|}
\hline Christianity & kind Jesus & $\begin{array}{l}\text { crucifixion of } \\
\text { Jesus }\end{array}$ & $\begin{array}{l}\text { righteousness through } \\
\text { faith }\end{array}$ & $\begin{array}{l}\text { elected by } \\
\text { God }\end{array}$ \\
\hline Judaism & $\begin{array}{l}\text { self-righteous Phari- } \\
\text { sees }\end{array}$ & deicides & $\begin{array}{l}\text { righteousness through } \\
\text { work }\end{array}$ & $\begin{array}{l}\text { rejected by } \\
\text { God }\end{array}$ \\
\hline
\end{tabular}

Herein lies one of the roots of enmity towards Judaism if not its principle origin. Throughout history, Judaism has served as a foil for Christian worldviews and as the antithesis of Christian identity. To illustrate this, Hoffmann quotes from a Protestant church newspaper published in 1865: "Since Golgotha, Judaism has

2 Cf. G. Harder, “Kontinuität und Diskontinuität des Gottesvolkes," in Kirche und Israel: Arbeiten zum christlich-jüdischen Verhältnis, ed. G. Harder (Berlin: Selbstverlag Institut Kirche und Judentum, 1986), 155-69.

3 Cf. C. Hoffmann, "Das Judentum als Antithese: Zur Tradition eines kulturellen Wertungsmusters," in Antisemitismus in der politischen Kultur nach 1945, ed. W. Bergmann and R. Erb (Opladen: Verlag für Sozialwissenschaften, 1990), 20-38.

4 Cf. Hoffmann, "Das Judentum als Antithese," $20 \mathrm{f}$.

5 Cf. ibid., 21. 
been at best an antiquated phenomenon; it is only through contrast that it holds any historical significance to life."6

\subsection{On the Historical Influence of Anti-Jewish Contrasting}

The consequences of this black-and-white thinking are devastating: Even as the influence of the church waned, the Christian West continued to use Jews as a negative foil for their own convictions. The reasons for this might be further detailed through prejudice psychology research, since contrasting and identity issues can form the basis for prejudice. As the following table shows, the religiously-motivated contrast scheme applies also to non-religious areas:

\begin{tabular}{lll}
\hline $\begin{array}{l}\text { "Christian” origins of the anti- } \\
\text { thetical valuation model }\end{array}$ & Jews \\
\hline & (humane) Jesus & self-righteous Pharisees \\
\hline & crucifixion of Jesus & deicides \\
\hline & righteousness through faith & $\begin{array}{l}\text { righteousness through } \\
\text { works }\end{array}$ \\
\hline Transfer to non-religious areas & elected by God & rejected by God \\
\hline Enlightenment & reason (e.g., enlightened & superstition (e.g., Judaism) \\
\hline pre-March 1848 & Greeks or Chinese) & \\
\hline "German” (i.e., national- & “Jewish” (i.e., liberal or \\
\hline racial doctrine & conservative) politics & democratic) politics \\
\hline
\end{tabular}

With the onset of the Enlightenment, the Christian aspect of this dualistic valuation gradually receded as the new identity and the newly secularized world emerged. And yet, despite the beginning of Jewish emancipation and such literary efforts as Lessing's Nathan the Wise, Judaism continued to serve as the antithesis of one's sense of identity. When exemplifying the Enlightenment ideals of "reason" and "the secular state," the Chinese and Greeks served as the "en-

6 Ibid., 23. Translation by the author of this article. 
lightened" models, while the Jews were associated with the antithetical ideals of "superstition" and theocracy."7

This phenomenon may also be observed in the Counter-Enlightenment. Indeed, the substantive content of the antithetical "Jew-German" valuation can only be understood historically as emerging from a backlash against Jewish emancipation. "By making reference to the Christian and Germanic character of the German 'folk spirit,' the 'foreignness' and 'otherness' of Jews was emphasized and the integration of Jews in German society rejected." In this sense, there are some documents of conservative politicians who, for instance, during the pre-March 1848 period decried their democratic opponents as "un-German" and "Jewish." Richard Wagner is also a classic proponent of this kind of thought, as is clear from the distinction he made between German, in other words, great music, and Jewish, or bad music. ${ }^{10}$

This antithetical valuation is likewise instructive when it comes to the racial doctrine of the Third Reich. As a German, I feel ashamed that in the Third Reich, the "Jewish race" served as the "dark" foil to the "Aryan race": Surely, this pseudo-scientific racial doctrine has its historical roots in-among other things-an abridged Darwinism and thus primarily in a secular context. But the question remains whether the specific formation of "racist" antisemitism could be completely explained without the prior existence of "Christian" antisemitism and the lasting impression it had made on Western culture. I think it is not possible, as we have to take into account, that under the racist doctrine, the Jews are not only one inferior race among others, such as the Slavs or the Roma-no, the Jews

7 Cf. Hoffmann, "Das Judentum als Antithese," 24.

8 Ibid., 27, translation by the author of this article. Also see R. Rendtorff and E. W. Stegemann, Auschwitz-Krise der christlichen Theologie: Eine Vortragsreihe (München: Kaiser, 1980), 13: “Thus the Jew joined the Frenchman-and even then, more permanently than him-as the counterimage of that which ideologically constituted the German national spirit.” Translation by the author of this article.

However, one should also not proceed in an undifferentiated manner from a unified "image of the Jews"- compare here, for instance, the analysis of pilgrims' reports from the nineteenth century by M. Langer, "Objektivität-Vorurteil-Feindschaft: Zur Ambivalenz der Wahrnehmung der Juden Palästinas in Katholischen Pilgerberichten des 19. Jahrhunderts," in Beziehungen zwischen Orient und Okzident. Interdisziplinäre und interregionale Forschungen, ed. M. Büttner and W. Leitner (Bochum: Brockmeyer,1992), 123-54.

9 Cf. Hoffmann, "Das Judentum als Antithese," 27; cf. also J. Katz, Vom Vorurteil bis zur Vernichtung: Der Antisemitismus 1700-1933 (Berlin: Union Verlag, 1990), 23-29.

10 Cf. "Das Judentum als Antithese,” 27, as well as S. Bergler, “'Erlösung dem Erlöser:' Richard Wagner (1813-1883) zwischen Antisemitismus und Antijudaismus,” Judaica 48 (1992): 165-76, especially 174 . 
are the (!) "anti-race," whose goal it is to subvert the Aryan race. ${ }^{11}$ How could this be explained without resorting to the Christian antithetical valuation, which posits the Jews as the antithesis of Christian Identity?

\section{Anti-Jewish Contrasting in Religious Education $^{12}$}

Between 1980 and 1995, several studies examined the topic of anti-Judaism in Germany and Austria through an analysis of religious educational textbooks and curricula. ${ }^{13}$ The results of those studies corresponded with other analyses of antisemitism in the context of religious education and can be effectively explained using different theories of prejudice. In the following, the results of the religious educational analyses from that time period will be presented first, followed by the present study of Julia Spichal. ${ }^{14}$

\subsection{Previous Studies of Textbooks and Curricula}

The representation of Judaism in textbooks and curricula can be characterized by an ambivalence that could be summarized with the formula "between reform and stagnation." Namely, a comparative analysis of this topic-regardless of all ongoing reform processes-reveals the following critical topics, within which curricula and textbooks presented Judaism in a problematic light: (1) Passion,

11 Cf. W. Hofer, “Stufen der Judenverfolgung im Dritten Reich 1933-1939," in Antisemitismus. Von der Judenfeindschaft zum Holocaust, ed. H. A. Strauss and N. Kampe (Frankfurt: Campus, 1985), 172-85.

12 The following section is a shortened and slightly modified version of M. Rothgangel, "AntiSemitism as a Challenge for Religious Education," in Religious Education: Between Radicalism and Tolerance, ed. E. Aslan and M. Rausch (Wiesbaden: Springer, 2018), 35-51, esp. 39-48. 13 The respective publications are discussed in M. Rothgangel, Antisemitismus als religionspädagogische Herausforderung. Eine Studie unter besonderer Berücksichtigung von Röm 9-11 (Freiburg: Herder, 1997), 114-27. For the following cf. also M. Rothgangel and J. Spichal, "Antijudaismus in Schulbüchern und Lehrplänen. Zwischen Reform und Stagnation,” Zeitschrift für Neues Testament 37 (2016): 58-66.

14 J. Spichal, Vorurteile gegen Juden im christlichen Religionsunterricht. Eine qualitative Inhaltsanalyse ausgewählter Lehrpläne und Schulbücher in Deutschland und Österreich (Göttingen: V\&R unipress, 2015). 
(2) Torah, (3) Pharisees, (4) “Old” Testament, (5) Jewish history, and (6) a generally insufficient definition of the Judeo-Christian relationship. ${ }^{15}$

The findings may be exemplified by the representation of "the" Pharisees as well as the treatment of the Torah in religious educational teaching materials: Although the authors of the textbooks and curricula clearly had good intentions when they accurately describe the Pharisees as a religious group in Jesus' time. However, "when in the same book-sometimes only a few pages later-the Pharisees appear in opposition to Jesus, they are depicted subjectively, negatively and tendentiously." ${ }^{\prime 16}$ A similar problem can be observed in the treatment of the Torah. As long as the Torah is discussed within the context of Judaism-that is, without being brought into relation to Jesus or Pauline or Christian thought -the authors make a serious effort to present an adequate picture of the Torah and its vital importance to everyday Jewish life. However, when the subject of the Torah is taught within the context of Jesus or Paul or topics like "violence and peace," the tendency to caricature the Torah as a negative expression of Jewish righteousness becomes apparent. Michael Brocke and Herbert Jochum assert quite rightly that "almost without exception, the positive approaches find their limits at the educational instrument of contrast."17

Fundamentally, such findings elucidate a challenge not only for religious education but for Christian theology as a whole. It turns out that religious education lacks a reasonable definition of the relationship between Judaism and Christianity-"reasonable" here meaning one in which Christian identity is neither left to inference, nor posited at the expense of Judaism. Indeed, between 1980 and 1995, numerous religious education scholars pointed out the negative consequences of this insufficient definition of the Christian-Jewish relationship. ${ }^{18} \mathrm{Ul}-$ timately, it is religious education teachers who are directly affected by this: "When, for example, [a teacher] attempts to depict Judaism in Jesus' time in a differentiated and sympathetic manner and comes up with praise for the

15 Cf. Rothgangel, Antisemitismus, 121-27. Translation by the author of this article.

16 H. Kemers, "Die wichtigsten Ergebnisse aus der Analyse der gegenwärtigen religionspädagogischen Literatur und die Frage nach den Konsequenzen," in Liebe und Gerechtigkeit: Gesammelte Beiträge, ed. H. Kremers, A. Weyer, and Th. Kremers-Sper (Neukirchen-Vluyn: Neukirchener Verlag, 1990), 233.

17 M. Brocke and H. Jochum, "Das Judentum in Schulbüchern für den katholischen Religionsunterricht heute - eine Problemanzeige," in Juden, Judentum und Staat Israel im christlichen Religionsunterricht in der Bundesrepublik Deutschland. Untersuchungen im Rahmen des Forschungsschwerpunkts 'Geschichte und Religion des Judentums' an der Universität DuisburgGesamthochschule, ed. H. Jochum and H. Kremers (Paderborn: Schöningh, 1980), 67. Translation by the author of this article.

18 Cf. the respective references in Rothgangel, Antisemitismus, 125-27. 
pious among the Pharisees-then [he or she] finds it difficult to justify what was new about what Jesus brought into the world. [This stands] in stark contrast to [a teacher] who works with a vivid image of the enemy, since the credibility of the new springs on its own from the decadence of the old."19 Helga Kohler-Spiegel arrives at a similar conclusion through her analysis of German, Austrian, and Swiss-German curricula: "How can Christians formulate the 'unique characteristics of Christianity' and their identity in a positive manner without resorting to negative demarcations in regard to Judaism?"20

\subsection{The Present Study of Julia Spichal}

It is remarkable that in the nearly twenty years since the initial studies, there have been no similar analyses regarding the handling of Judaism within Protestant and Catholic religious education. The dissertation of Julia Spichal fills this research gap and seeks to identify the developments that have taken place in the intervening decades. ${ }^{21}$ Julia Spichal's study used comparable syllabi and textbooks as well as Fiedler's analysis grid (1980). This was essential to ensure a reliable comparison with the previous textbook and syllabus analyses. In addition, she used content analysis for data analysis but in a form developed by Philipp Mayring. $^{22}$

From her analysis, one of the neuralgic points mentioned in 2.1 is exemplified here, namely the Jewish understanding of the Torah: In the fourth volume of the Wegzeichen Religion textbook series, the Jewish interpretation of the Torah is treated in conjunction with the topic of Paul. The schoolbook builds a factually false contrast between the Torah and faith in Jesus Christ by raising the question of whether Judaism or Christianity is "right" about faith. ${ }^{23}$ In contrast to this, the 1977 edition does not contain any distortion of the Jewish understanding of the

19 Cf. H. Sorge, "Judentum. Didaktische Skizze mit einer Projektidee für die Sekundarstufe II," ForR, no. 3 (1983): 14. Translation by the author of this article.

20 H. Kohler-Spiegel, Juden und Christen-Geschwister im Glauben: Ein Beitrag zur Lehrplantheorie am Beispiel Verhältnis Christentum Judentum (Freiburg: Herder, 1991), 323. Translation by the author of this article.

21 Cf. Spichal, Vorurteile.

22 Cf. ibid.

23 Cf. S. Beck-Seiferlein et al., Wegzeichen Religion 4. Ein Unterrichtswerk für den Evangelischen Religionsunterricht in der Jahrgangsstufe 4 (Frankfurt a. M.: Diesterweg, 2004), 64. 
Torah in the context of Paul; on the contrary, an effort is made to provide a benevolent representation. ${ }^{24}$ This should therefore be viewed as a negative change.

In a similar way, the textbook Da sein-Wege ins Leben, volume 7, offers a factually false picture of the Jewish understanding of the Torah. This textbook suggests that Jesus' critique of the Torah was the reason why Paul persecuted the "Christians" 25 and thereby absolutizes the Pauline Torah critique. Furthermore, it characterizes the Torah as constricting ${ }^{26}$ and thereby contradicts the 2004 curriculum guidelines for Bavarian general schools, where although the term "law" is used in a separate chapter on Judaism, the Torah is characterized as a reason for joy instead of a burden. ${ }^{27}$ On the other hand, the 1983 curriculum for Bavarian general schools presented Judaism as a negative foil for Christian doctrine, which means the change since then has been a positive development.

In addition to the serious findings listed above, the examined material also contains explicitly positive statements. For example, the school book series $R e$ ligion entdecken-verstehen-gestalten explicitly states that different interpretations of the Torah are the usual practice within Judaism. ${ }^{28}$ In this manner, the textbook avoids presenting students with a false opposition between the Torah of Jesus and the Pharisees. This danger is also avoided when dealing with Paul by emphasizing the relevance of the Torah to early Christianity. However, a "new law"29 is mentioned here, which leads the text to give a contradictory impression of its earlier mention of the Torah's permanent relevance.

An equally favorable description is found in the curriculum for Austrian elementary schools. Here, the Torah is described as a "way of salvation" for Israel and as a gift from God. ${ }^{30}$ It is noteworthy, however, that the Christian-Jewish relationship is not addressed. Thus, there is no information on the relevance of the Torah for Jesus and early Christianity.

The explanations in the REli+wir textbook seem very similar to this. This textbook also emphasizes that rather than being a constraint, the Torah liberates

24 Cf. Rothgangel, Antisemitismus, 138-39.

25 Cf. W. Haußmann et al., Da sein-Wege ins Leben 7. Ein Unterrichtswerk für den Evangelischen Religionsunterricht an Hauptschulen (Braunschweig: Diesterweg, 2001), 110.

26 Cf. ibid.

27 Cf. Bayerisches Staatsministerium für Unterricht und Kultus, ed. Lehrpläne für die Hauptschule Jahrgangsstufen 5 bis 9 (München, 2004), 95.

28 G.-R. Koretzki and R. Tammeus, ed., Religion entdecken-verstehen-gestalten. 5./6. Schuljahr (Göttingen: Vandenhoeck \& Ruprecht, 2008), 69.

29 Ibid., 101.

30 Cf. Bundeskanzleramt, ed., Bundesgesetzblatt für die Republik Österreich, 255. Bekanntmachung: Lehrpläne für den katholischen Religionsunterricht an Volksschulen und für den evangelischen Religionsunterricht an Volksschulen und an Sonderschulen, Teil II (Wien, 2010), 24. 
people to life. ${ }^{31}$ Compared to the contrast that the same textbook draws between Jesus' interpretation of the Sabbath and that of "the Jews," however, it is clear that the Jewish understanding of the Torah, which is allegedly hostile to life, here serves as a negative foil to promote the merciful Christian message. Thus, the text presents the very discrepancy that Fiedler has already problematized, namely, the discrepancy between a benevolent depiction of the Torah on the one hand, and a factually false caricature of the Jewish Torah in contrast to Jesus' message, on the other.

Therefore, Spichal's analysis of currently-approved textbooks and curricula leads to the conclusion that there are still clear anti-Jewish polemics to be found in several places regarding the Jewish interpretations of the Torah. In relative terms, her analysis leads to a result similar to the textbook and curriculum analysis of the 1980s and mid-1990s. On the one hand, in certain textbooks and curricula there have indeed been comparatively positive revisions regarding critical points concerning the treatment of Judaism in religious education. It is worth noting, however, that there are other religious educational textbooks and curricula in which tendentious and factually-inaccurate representations prevail, and in which very occasionally, we may even observe regressions in this regard. Overall, there is a clear need for revision in numerous, currently-approved curricula and textbooks.

This result is sobering and shows that the implementation of the findings of religious education research in religious educational teaching materials is a lengthy process. The negative effects of this problem become obvious, when we take into account the following psychological perspectives.

\section{Psychological Perspectives on Anti-Jewish Contrasting $^{32}$}

Before examining the significance of psychological theories of prejudice to antiJewish contrasting, one should first consider and outline the different ways of understanding the underlying concepts of attitude and prejudice.

31 Evangelischer Presseverband Österreich, ed., RELi+wir (Göttingen: Vandenhoeck \& Ruprecht, 2010), 293.

32 The following section is a shortened and slightly modified version of M. Rothgangel, "Interreligious Education in the Context of Social Psychology Research on Attitudes and Prejudice," HTS Teologiese Studies/Theological Studies 72, no. 4 (2016): 1-9. 


\subsection{Attitude and Prejudice-Conceptual Definitions}

Attitude is a well-studied construct in social psychology. One may define it as "a person's predisposition or inclination to evaluate an object or its symbolic representations in a particular way or manner." ${ }^{33}$ Additionally, under the well-established attitudes model of Eagly \& Chaiken, attitudes are understood as comprehensive evaluations that exhibit affective, cognitive, as well as behavioral components. ${ }^{34}$ Under this model, the affective components of attitude refer to feelings or emotions; the cognitive components refer to thoughts and beliefs that are associated with a given subject; and, finally, the behavioral components refer to behaviors associated with the object under evaluation. The basic psychological need to evaluate an object, which underlies attitudes, derives from the preference for explicit answers to a topic, which are considered positive in contrast to ambiguity and confusing complexity. Attitudes thereby facilitate the formulation of judgment and the classification of topics as well as events.

Prejudice may be considered a subcategory of attitude and defined as a negative attitude toward people or groups of people. ${ }^{35}$ From this definition emerges the negatively-evaluated aspect of "pre-judgment," which always includes preand misjudgments. Similarly to attitude, prejudice may also be analyzed as having cognitive (e.g., stereotype), affective (e. g., resentment), and behavioral (e.g., readiness to discriminate) components. The function of prejudice lies in the growth of one's self-esteem or sense of belonging as a result of the devaluation of another person or group. The aim of the following considerations is to determine in which sense anti-Jewish contrasting functions as a form of prejudice.

\subsection{Antisemitism as "a Categorization Problem"- Accentuation Theory}

In the late 1960s, psychology underwent the so-called cognitive revolution. In prejudice research, psychological explanatory models like scapegoat theory or studies about the authoritarian personality were largely supplanted by theories that explained the emergence of prejudices in "natural" processes of thought and

33 N. M. Seel, Psychologie des Lernens (München: UTB, 2000), 118.

34 Cf. A. H. Eagly and S. Chaiken, The Psychology of Attitudes (Fort Worth: Harcourt, Brace, \& Janovich, 1993).

35 Though this definition of prejudice is by no means uncontroversial in social psychology, it nonetheless represents a widespread trend (for more detail, cf. Rothgangel, Antisemitismus, 18-21). 
perception. In the following, the focus will be on one of these cognitive theories, the accentuation theory.

It is well known from perception psychology that a person can absorb and process only a portion of the sensory information available to him or her in the surrounding world. This makes the development of "reduction strategies" especially necessary. ${ }^{36}$ Accordingly, social prejudices should not be merely understood as "false" judgments. Rather, they represent the natural and inevitable consequence of the processing of social stimuli and provide guidance in a complex outer world. ${ }^{37}$

In the categorisation of people, a decisive role is played by physical as well as social traits like ethnic or religious membership. We may understand social prejudice as an assumed correlation between a particular category (e.g., Italian) and one or several traits (e.g., body size). This leads, however, to the accentuation of differences between the traits of different categories-in this sense, traits that mark differences are emphasised or exaggerated. In practice this means that a person's membership of different groups (for instance Italian or Swedish) can lead to an overemphasis on the perception of differences ("the" Swedes are larger than "the" Italians). Numerous empirical studies demonstrate accentuation effects in physical as well as social stimuli.

Because of the complexity of the social environment, accentuation effects related to social prejudice arise primarily as a result of social influence and less as a result of observation. This, in turn, suggests that accentuation theory lends itself more to studying macro factors of socialisation and learning theory. The founder of accentuation theory, H. Tajfel, later extended his explanatory model with the social identity theory, in which he supplemented his use of certain thought processes to explain prejudice formation with human motives and needs. Applied on its own, accentuation theory can explain why differences between two groups are emphasized. Its limitations, however, lie in its inability to explain why other groups are frequently devalued in relation to one's own group. Accordingly, H. Tajfel refers in his later modified view of "social identity theory" to an essential difference between social prejudice and other cognitive categories: As a rule, prejudices about outgroups are less positive in relation to the ingroup-that is, a purely cognitive explanation does not enable us to interpret ad-

36 Cf. J.-P. Leyens and J.-P. Codol, "Soziale Informationsverarbeitung," in Sozialpsychologie, ed. W. Stroebe, M. Hewstone, J.-P. Codol, and G. M. Stephenson (Berlin: Springer, 1990), 92.

37 Cf. H. Tajfel, “Cognitive Aspects of Prejudice,” Journal of Social Issues 25 (1969): 82; U. Six, "Ethnische Vorurteile. Möglichkeiten und Grenzen ihrer Reduktion durch Massenmedien," in Vorurteile und Einstellungen: Sozialpsychologische Beiträge zum Problem sozialer Orientierung, ed. B. Schäfer and F. Petermann (Köln: Deutscher Instituts Verlag, 1988), 327. 
equately an ethnocentric attitude that is widely observed among a group of people. $^{38}$

\subsection{Antisemitism as a Problem of Identity-Social Identity Theory}

When it comes to the so-called "conflict theories," we may distinguish between the realistic conflict theory and the social identity theory. ${ }^{39}$ According to the realistic conflict theory, political, economic, etc. conflicts between groups result in a perception of threat, the consequence of which is again ethnocentrism-that is, enhanced solidarity within the ingroup and a devaluation of the competing outgroup. ${ }^{40}$

For the analysis of religious prejudice, however, the social identity theory ${ }^{41}$ deserves more attention, as it provides well-founded corrections and additions to the realistic conflict theory: First, the perception of belonging to one of two groups alone can lead one to prefer one's own group and disadvantage the other group. Second, not every group conflict needs to lead to ethnocentrism, since an effective antidote might be, for example, the provision of an institutional framework that mediates competition between groups. Third, conflicts might arise not only over "physical" resources but also over social prestige and social status. ${ }^{42}$ With the help of social identity theory, these criticisms may be integrated into a self-contained explanatory model. One could say that the inherent

38 Cf. W. Stroebe et al., "Stereotype, Prejudice and Discrimination: Changing Conceptions in Theory and Research," in Stereotyping and Prejudice: Changing Conceptions, ed. D. Bar-Tal, C. F. Graumann, A. W. Kruglanski, and W. Stroebe (New York: Springer, 1989), 5.

39 On the Realistic Conflict Theory, cf. D. Campbell, "Ethnocentrism and Other Altruistic Motives," in Nebraska Symposium on Motivation, ed. D. Levine (Lincoln: University of Nebraska Press, 1965), 283-311, and M. Sherif, Group Conflict and Co-operation: Their Social Psychology (London: Routledge \& Kegan Paul, 1966). On the Social Identity Theory, cf. H. Tajfel, Gruppenkonflikt und Vorurteil. Entstehung und Funktion sozialer Stereotypen (Wien: Huber, 1982).

40 Cf. Stroebe et al., "Stereotype," 14.

41 Petersen and Blank offer an up-to-date overview of this theory. For the significance of this theory, cf. L.-E. Petersen and H. Blank, "Das Paradigma der minimalen Gruppen,” in Stereotype, Vorurteile und soziale Diskriminierung: Theorien, Befunde und Interventionen, ed. L.-E. Petersen and B. Six (Basel: Beltz, 2008), 200 -213; L.-E. Petersen, "Die Theorie der sozialen Identität," in Stereotype, Vorurteile und soziale Diskriminierung: Theorien, Befunde und Interventionen, ed. L.-E. Petersen and B. Six (Basel: Beltz, 2008), 223-30. "The minimal group paradigm has been the dominant research paradigm in social discrimination research during the last four decades." Petersen and Blank, "Das Paradigma," 200. Translation by the author of this article. 42 Cf. Stroebe et al., "Stereotype," 14. 
human desire for a positive social identity represents the Archimedean fulcrum point of this theory. ${ }^{43}$

This situation can be illustrated by means of the "minimal intergroup" experiments. ${ }^{44}$ In these experiments, research participants were aware of their own group membership and the group membership of those among whom they were asked to distribute money. However, research participants knew the individuals of the ingroup and the outgroup only through code numbers. ${ }^{45}$ In one such experiment, three "money distribution strategies" were available to choose from: the first entailed a maximum shared win for both groups; the second, maximum profit for the ingroup; and the third, a maximum difference between the groups in favor of the ingroup. ${ }^{46}$ Tajfel justified these requirements as follows:

There was no externally defined conflict in our experiments; if there was competition (i.e., actions aimed at differentiating between the groups in favor of one's own), then it was actively introduced to the situation by the participants themselves as soon as the researchers introduced the concept of a group. Research participants were never together in a 'group'; they did not interact, nor did they know who belonged to the outgroup or to their ingroup; there was no explicit social pressure to act in favor of their own group, nor was it in the interest of the research participants to grant the members of their own group more money. On the contrary, had they consistently pursued a strategy of maximum joint profit, they would all have received more money from the researcher. ${ }^{47}$

Nevertheless, the third "money distribution strategy," the one providing maximum difference in favor of the ingroup, predominated. The minimal intergroup experiments therefore reveal a need to focus on positive ways to distinguish oneself from other groups. ${ }^{48}$ This striving for a positive trait manifests itself in various social and cultural interactions. ${ }^{49}$

43 Tajfel defines social identity as "that part of an individual's self-image [...] that is derived from the knowledge of his or her membership in social groups and from the value and emotional meaning that this membership carries.” Tajfel, Gruppenkonflikt und Vorurteil, 102. Translation by the author of this article.

44 The so-called "minimal intergroup experiments" were conducted to determine the minimal conditions under which an individual would demonstrate a noticeable difference in his or her behavior in favor of an ingroup versus an outgroup. Cf. Tajfel, Gruppenkonflikt, 118.

45 Cf. ibid.

46 Cf. ibid., 119.

47 Ibid.,124. Translation by the author of this article.

48 Cf. ibid., 121-25.

49 Cf. ibid., 126. 
Since the status of the ingroup represents an important determinant of social identity, low social status motivates the members of a group to join another group of higher status or to improve the status of their own group..$^{50}$ Conversely, members of the "superior" group seek to defend their status against groups that threaten or appear to threaten it and justify their status anew if they see it associated with a conflict of values (e.g., if the higher status is based on unjust prejudices). ${ }^{51}$ Under the social identity theory, prejudices may, for instance, be viewed as an effective means to present one's own group in a better light or to justify its unfair advantages. The purpose of such measures lies, in the former case, in the indirect improvement of the ingroup's status and, in the latter case, in the justification of the lower social status of the outgroup.

In conclusion, it should nevertheless be stressed that social identity theory is not a "catch-all" framework for antisemitic prejudice. ${ }^{52}$ It does not, therefore, take into account the role that, for example, parents or other agents of socialization-the importance of which is discussed below-play in prejudice formation.

\subsection{Antisemitism as Socialization Problem-Social Learning Theory}

Education plays an important role in maintaining subcultures and therefore also in the passing on of religious prejudice. Children whose parents espouse antisemitic or Islamophobic values learn these prejudices from their parents. It is primarily educational content that is responsible for prejudice formation and dissemination, not, for example, an authoritarian style of parenting. ${ }^{53}$ In contrast to scapegoat theory, proponents of social learning theory ${ }^{54}$ do not presuppose a motive which leads to the devaluation of other groups. Social prejudices arise either from the observation of existing differences between different social

50 Cf. ibid., 103.

51 Cf. ibid., $132 \mathrm{f}$.

52 The current state of social identity theory, as well as its limitations and prospects for further development, are thoroughly discussed in A. Zick, "Die Konflikttheorie der Theorie sozialer Identität," in Sozialwissenschaftliche Konflikttheorien: Eine Einführung, ed. T. Bonacker (Wiesbaden: Verlag für Sozialwissenschaften, 2008), 409-26.

53 Cf. H. Weiss, "Antisemitische Vorurteile in Österreich nach 1945. Ergebnisse empirischer Forschungen," in Antisemitismus nach dem Holocaust. Bestandsaufnahme und Erscheinungsformen in deutschsprachigen Ländern, ed. A. Silbermann and J. H. Schoeps (Köln: Verlag Wissenschaft und Politik, 1986), 62.

54 Cf. A. Bandura, Social Learning Theory (New York: General Learning Press, 1977). 
groups or from social influences that one may be exposed to in the course of one's life through parents, peers, school, and the mass media. ${ }^{55}$

Such prejudices are ultimately passed down by agents of socialization such as family, peers, schools, and the mass media. Since racial, ethnic, and gender prejudices are acquired at a relatively early stage of life (from around the age of four), ${ }^{56}$ parents play a very significant role in this process. A child learns these prejudices, on the one hand, through the linguistic information it receives from its parents and, on the other, through the learning model provided by the parents' behavior. ${ }^{57}$ The consequences that parents experience as a result of their own demonstrated behavior are major determinants for whether the child engages in or avoids the same behavior.

The less education a person has, the less likely it is that he or she will understand a complex phenomenon-such as his or her social environment-in intellectual terms. Likewise, s/he will be less likely to accept ambiguity. Selznick and Steinberg refer to this situation as simplicity and use surveys to demonstrate that simplicity steadily decreases with a rise in education level. ${ }^{58}$ It is worth noting at this point that a lack of education is also accompanied by a lack of ethical sensitivity, which leads to the acceptance of attitudes that include inhumane or intolerant ideas. ${ }^{59}$ Accordingly, a rise in "simplicity" is accompanied by a significant increase in the incidence of antisemitic attitudes. ${ }^{60}$ Simplicity, however, is far from being a purely cognitive phenomenon. It also has an impact on an emo-

55 Cf. Stroebe et al., "Stereotype," 15.

56 Ethnic prejudices are acquired between the ages of three and five, cf. F. E. Aboud, Children and Prejudice (London: Blackwell, 1988), 43. Further discussion of this issue may be found in W. Bergmann, "Attitude Theory and Prejudice," in Error Without Trial: Psychological Research on Antisemitism, ed. W. Bergmann (Berlin: de Gruyter, 1988), 280; for an illustrative example with third graders, see E. Aronson, T. D. Wilson, and R. M. Akert, Sozialpsychologie (London: Pearson, 2008), $430 \mathrm{f}$.

57 Cf. Stroebe et al., "Stereotype," 16.

58 Lower "simplicity" is found among 9 percent of people with only a primary education, 18 percent with a high school education, 34 percent with some college education and 49 percent with a full college education. Conversely, higher "simplicity" is found among 51 percent of people with only a primary education, 34 percent with a high school education, 15 percent with some college education and 9 percent with a full college education. Cf. G. J. Selznick and S. Steinberg, The Tenacity of Prejudice: Anti-Semitism in Contemporary America (New York: Harper \& Row, 1969), 141.

59 Cf. Selznick and Steinberg, The Tenacity of Prejudice, 141.

60 "As simplicity goes from low to medium to high, the proportion of antisemitism rises from 17 to 39 to 64 percent.” Ibid., $142 \mathrm{f}$. 
tional level, since lacking cognitive differentiation and accepting intolerant opinions entails further psychological consequences. ${ }^{61}$

The discussion of the various psychological theories shows us that none of these theories can generally explain the origin and function of antisemitic prejudices. To sum up, we find that in the context of cognitive theories, antisemitic prejudice functions as a categorisation problem; in the context of social identity theory, antisemitic prejudice functions as an identity problem; and in the context of social learning theory, it functions as a socialisation problem. The three discussed psychological theories also offer us strategies for combatting antisemitic prejudices as mentioned in the historical and religious educational part.

Nevertheless, at this point, it is worth drawing attention to another conundrum: In the fields of attitude and prejudice psychology, we can currently observe the predicament that evidence-based theories of attitude change or prejudice reduction ${ }^{62}$ were developed relatively independently of the theories of prejudice formation and function discussed above. The elimination of this research deficit has even been described as "the most exciting challenge" ${ }^{63}$ of the coming decades. This "gap" notwithstanding, we can derive specific evidence-based theories of attitude and prejudice from the enumerated theories and formulate conditions under which religious education can contribute to combat antisemitism.

61 Cf. ibid., 142, 168.

62 Cf., for example, S. Oskamp, ed., Reducing Prejudice and Discrimination (London: Lawrence Erlbaum Associates, 2000). Much discussed is the contact hypothesis, cf. T. F. Pettigrew and L. R. Troop, "Does Intergroup Contact Reduce Prejudice? Recent Meta-Analytic Findings," in Reducing Prejudice and Discrimination, ed. S. Oskamp (London: Lawrence Erlbaum Associates, 2000), 93114; S. Stürmer, "Die Kontakthypothese," in Stereotype, Vorurteile und soziale Diskriminierung: Theorien, Befunde und Interventionen, ed. L.-E. Petersen and B. Six (Basel: Beltz, 2008), 283-91. 63 W. D. Crano, J. Cooper, and J. P. Forgas, eds., The Psychology of Attitudes and Attitude Changed (New York: Psychology Press, 2010), 13. In comparison to other areas of prejudice research, there have been relatively few studies on prejudice reduction. Nevertheless, there has been a wide range of research since the mid-1980s that investigates the possibility of arriving at an empirical synthesis of contact theory and social identity theory (cf. M. B. Brewer, "Reducing Prejudice through Cross-categorization: Effects of Multiple Social Identities,” in Reducing Prejudice and Discrimination, ed. S. Oskamp (London: Lawrence Erlbaum Associates, 2000), 165. 


\section{Combatting Antisemitism}

\subsection{Immediate Prospects for Combatting Antisemitism in Light of the Accentuation Theory}

Strictly speaking, accentuation theory tells us that the mere juxtaposition of Christianity and Judaism can lead to an accentuation of the differences between these two religions. And in the light of the accentuation theory, it is obvious that anti-Jewish contrasting, as shown in the historical and religious educational part, is one important source of prejudices against Jews and Judaism.

An effective way to counteract accentuation processes is cross-categorisation. Here, the existing categorisation into Christians and Jews is not simply negated but is in some way relativized or "crisscrossed." This means that, in addition to existing differences, one has to highlight, from a Christian perspective, the overarching similarities between Christianity and Judaism, for instance the rootedness of Christianity in Judaism. However, members of religious groups may perceive these strategies as a threat to their religious identity and refuse to implement them. For this reason the following point has also been taken into consideration.

\subsection{Immediate Prospects for Combatting Antisemitism in Light of the Social Identity Theory}

As mentioned before, the mere perception of membership in a different group can lead a priori to the favouring of one's own religion and discrimination of members of another religion. According to social identity theory, prejudices against other religions contribute to securing one's own religious identity. In contrast to the cognitive-structural theories, social identity theory can explain why from a Christian perspective there is the tendency to devalue Judaism. However, this discrimination process will not take place, if the devaluation of the other religion leads also to a devaluation of one's own religion. For this reason, the following words of Paul in Romans 11:18 are very important for Christian education: "do not consider yourself to be superior to those other branches. If you do, consider this: You do not support the root, but the root supports you." By mentioning the realm of Christian education, there is only one step to move on to the following part. 


\subsection{Immediate Prospects for Combatting Antisemitism in Light of the Social Learning Theory}

The analysis of religious antisemitism benefits from the inclusion of social learning theory: Here, the importance of social influences and subcultural values becomes evident. In this sense, one has to consider the coexistence of different cultures and subcultures. For instance, antisemitism by right-wing or Islamist groups or antisemitism in the digital world-and also we have to consider what has been said regarding the anti-Jewish contrasting in religious education. Antisemitic prejudices are therefore acquired by the "completely normal" process of socialisation within different cultures and subcultures full of antisemitic prejudices-and only some of them are totally evident, others are subtle as for instance the mere contrasting of Christianity and Judaism.

For these reasons, there is a need for conferences and projects that establish measures against antisemitic subcultures in an interdisciplinary way. Perhaps the previous considerations have shown how the different perspectives, the historical, the religious educational, and last but not least the psychological, shed light upon each other. We do need these interdisciplinary approaches to combat antisemitism. Nevertheless, there is still a lack of empirical research of what educational measurements are effective against antisemitism. Sometimes antisemitism might appear as an everlasting phenomenon, but interdisciplinary research will increase the chance that there will be an end to it!

Martin Rothgangel is Professor for Religious Education in the Faculty of Protestant Theology at the University of Vienna. Main topics of his reasearch are "Antisemitism", "Theology and Natural Sciences", "Interreligious education", "Theory of Subject-matter Didactics" and "Philosophy of Science".

\section{Bibliography}

Aboud, Frances E. Children and Prejudice. London: Blackwell, 1988.

Aronson, Elliot, Timothy D. Wilson, and Robin M. Akert. Sozialpsychologie. London: Pearson, 2008.

Bandura, Albert. Social Learning Theory. New York: General Learning Press, 1977.

Bayerisches Staatsministerium für Unterricht und Kultus, ed. Lehrpläne für die Hauptschule Jahrgangsstufen 5 bis 9. München, 2004.

Beck-Seiferlein, Steffi, et al. Wegzeichen Religion 4. Ein Unterrichtswerk für den

Evangelischen Religionsunterricht in der Jahrgangsstufe 4. Frankfurt a. M.: Diesterweg, 2004. 
Bergler, S. “'Erlösung dem Erlöser:’ Richard Wagner (1813-1883) zwischen Antisemitismus und Antijudaismus." Judaica 48 (1992): 165-76.

Bergmann, Werner. "Attitude Theory and Prejudice." In Error Without Trial: Psychological Research on Antisemitism, edited by Werner Bergmann, 271-301. Berlin: de Gruyter, 1988.

Brewer, Marilynn B. "Reducing Prejudice through Cross-categorization: Effects of Multiple Social Identities." In Reducing Prejudice and Discrimination, edited by Stuart Oskamp, 165-83. London: Lawrence Erlbaum Associates, 2000.

Brocke, Michael, and Herbert Jochum. "Das Judentum in Schulbüchern für den katholischen Religionsunterricht heute-eine Problemanzeige." In Juden, Judentum und Staat Israel im christlichen Religionsunterricht in der Bundesrepublik Deutschland: Untersuchungen im Rahmen des Forschungsschwerpunkts 'Geschichte und Religion des Judentums' an der Universität Duisburg-Gesamthochschule, edited by Herbert Jochum and Heinz Kremers, 55-74. Paderborn: Schöningh, 1980.

Bundeskanzleramt, ed. Bundesgesetzblatt für die Republik Österreich, 255. Bekanntmachung: Lehrpläne für den katholischen Religionsunterricht an Volksschulen und für den evangelischen Religionsunterricht an Volksschulen und an Sonderschulen, Teil II. Wien, 2010.

Campbell, Donald T. "Ethnocentrism and Other Altruistic Motives." In Nebraska Symposium on Motivation, edited by D. Levine, 283-311. Lincoln: University of Nebraska Press, 1965.

Crano, William D., Joel Cooper, and Joseph P. Forgas, eds. The Psychology of Attitudes and Attitude Changed. New York: Psychology Press, 2010.

Evangelischer Presseverband Österreich, ed. RELi+wir. Göttingen: Evangelischer Presseverband in Österreich, 2010.

Harder, Günther "Kontinuität und Diskontinuität des Gottesvolkes." In Kirche und Israel: Arbeiten zum christlich-jüdischen Verhältnis, edited by Günther Harder, 155-69. Berlin: Selbstverlag Institut Kirche und Judentum, 1986.

Haußmann, Werner, et al. Da sein-Wege ins Leben 7. Ein Unterrichtswerk für den Evangelischen Religionsunterricht an Hauptschulen. Braunschweig: Diesterweg, 2001.

Hofer, Walther. "Stufen der Judenverfolgung im Dritten Reich 1933-1939." In Antisemitismus. Von der Judenfeindschaft zum Holocaust, edited by Herbert A. Strauss and Norbert Kampe, 172-85. Frankfurt: Campus, 1985.

Hoffmann, Christhard. "Das Judentum als Antithese. Zur Tradition eines kulturellen Wertungsmusters." In Antisemitismus in der politischen Kultur nach 1945, edited by Werner Bergmann and Rainer Erb, 20-38. Wiesbaden: Westdeutscher Verlag, 1990.

Katz, Jacob. Vom Vorurteil bis zur Vernichtung: Der Antisemitismus 1700-1933. Berlin: Union-Verlag, 1990.

Kohler-Spiegel, Helga. Juden und Christen-Geschwister im Glauben: Ein Beitrag zur Lehrplantheorie am Beispiel Verhältnis Christentum Judentum. Freiburg: Herder, 1991.

Koretzki Gerd-Rüdiger, and Rudolf Tammeus, eds. Religion entdecken-verstehen-gestalten. 5./6. Schuljahr. Göttingen: Vandenhoeck \& Ruprecht, 2008.

Kremers, Heinz. "Die wichtigsten Ergebnisse aus der Analyse der gegenwärtigen religionspädagogischen Literatur und die Frage nach den Konsequenzen." In Liebe und Gerechtigkeit. Gesammelte Beiträge, edited by Adam Weyer, 223-36. Neukirchen-Vluyn: Neukirchener Verlag, 1990. 
Langer, Michael. “Objektivität-Vorurteil-Feindschaft: Zur Ambivalenz der Wahrnehmung der Juden Palästinas in Katholischen Pilgerberichten des 19. Jahrhunderts.” In Beziehungen zwischen Orient und Okzident. Interdisziplinäre und interregionale Forschungen.

Ergebnisse des Symposiums Graz, 3. bis 6. September 1992, Teil 1, edited by Manfred Büttner and Wilhelm Leitner, 123-54. Bochum: Brockmeyer, 1992.

Leyens, Jacques-Philippe, and Jean-Paul Codol. "Soziale Informationsverarbeitung." In Sozialpsychologie, edited by Wolfgang Stroebe, Miles Hewstone, Jean-Paul Codol, and Geoffrey M. Stephenson, 89-90. Berlin: Springer, 1990.

Oskamp, Stuart. Reducing Prejudice and Discrimination. London: Lawrence Erlbaum Associates, 2000.

Petersen, Lars-Eric, and Hartmut Blank. "Das Paradigma der minimalen Gruppen.” In Stereotype, Vorurteile und soziale Diskriminierung: Theorien, Befunde und Interventionen, edited by Lars-Eric Petersen and Bernd Six, 200-213. Basel: Beltz, 2008.

Pettigrew, Thomas F., and Linda R. Troop. "Does Intergroup Contact Reduce Prejudice? Recent Meta-Analytic Findings." In Reducing Prejudice and Discrimination, edited by Stuart Oskamp, 93-114. London: Lawrence Erlbaum Associates, 2000.

Rendtorff, Rolf, and Ekkehard W. Stegemann. Auschwitz-Krise der christlichen Theologie: Eine Vortragsreihe. München: Kaiser 1980.

Rothgangel, Martin. "Anti-Semitism as a Challenge for Religious Education." In Religious Education: Between Radicalism and Tolerance, edited by Ednan Aslan and Margaret Rausch, 35-51. Wiesbaden: Springer, 2018.

Rothgangel, Martin. Antisemitismus als religionspädagogische Herausforderung. Eine Studie unter besonderer Berücksichtigung von Röm 9-11. Freiburg: Herder, 1997.

Rothgangel, Martin "Interreligious Education in the Context of Social Psychology Research on Attitudes and Prejudice." HTS Teologiese Studies/Theological Studies 72, no. 4 (2016): $1-9$.

Rothgangel, Martin, and Julia Spichal. "Antijudaismus in Schulbüchern und Lehrplänen. Zwischen Reform und Stagnation.” Zeitschrift für Neues Testament 37 (2016): 58-66.

Seel, Norbert M. Psychologie des Lernens. München: UTB, 2000.

Selznick, Gertrude J., and Stephen Steinberg. The Tenacity of Prejudice: Anti-Semitism in Contemporary America. New York: Harper \& Row, 1969.

Sherif, Muzafer. Group Conflict and Co-operation: Their Social Psychology. London: Routledge \& Kegan Paul, 1966.

Sorge, Helga. "Judentum. Didaktische Skizze mit einer Projektidee für die Sekundarstufe II." ForR, no. 3 (1983): 13-19.

Six, Ulrike. "Ethnische Vorurteile. Möglichkeiten und Grenzen ihrer Reduktion durch Massenmedien”. In Vorurteile und Einstellungen: Sozialpsychologische Beiträge zum Problem sozialer Orientierung, edited by Bernd Schäfer and Franz Petermann, 309-45. Köln: Deutscher Instituts Verlag, 1988.

Spichal, Julia. Vorurteile gegen Juden im christlichen Religionsunterricht. Eine qualitative Inhaltsanalyse ausgewählter Lehrpläne und Schulbücher in Deutschland und Österreich. Göttingen: V\&R unipress, 2015.

Stroebe Wolfgang, et al. "Stereotype, Prejudice and Discrimination: Changing Conceptions in Theory and Research." In Stereotyping and Prejudice: Changing Conceptions, edited by 
David Bar-Tal, Carl F. Graumann, Arie W. Kruglanski, and Wolfgan Stroebe, 3-34. New York: Springer, 1989.

Stürmer, Stefan. "Die Kontakthypothese." In Stereotype, Vorurteile und soziale

Diskriminierung: Theorien, Befunde und Interventionen, edited by Lars-Eric Petersen and Bernd Six, 283-91. Basel: Beltz, 2008.

Tajfel, Henri. “Cognitive Aspects of Prejudice.” Journal of Social Issues 25 (1969): 79-97.

Tajfel, Henri. Gruppenkonflikt und Vorurteil. Entstehung und Funktion sozialer Stereotypen.

Wien: Huber, 1982.

Weiss, Hilde. "Antisemitische Vorurteile in Österreich nach 1945. Ergebnisse empirischer

Forschungen." In Antisemitismus nach dem Holocaust. Bestandsaufnahme und

Erscheinungsformen in deutschsprachigen Ländern, edited by Alphons Silbermann and Julius H. Schoeps, 53-70. Köln: Verlag Wissenschaft und Politik, 1986.

Zick, Andreas. "Die Konflikttheorie der Theorie sozialer Identität.” In Sozialwissenschaftliche Konflikttheorien: Eine Einführung, edited by Thorsten Bonacker, 409-26. Wiesbaden: Verlag für Sozialwissenschaften, 2008. 
